\title{
Rorschach Psycho diagnosis: It's Contribution to the Knowledge of Binomy Personality-Culture
}

\author{
Jesus DB* \\ Honorary Member, Scuola Romana Rorschach, Department of the Psychiatric \\ Hospital of Havana, Cuba
}

*Corresponding author: Jesús Dueñas Becerra, Honorary Member, Scuola Romana

\section{Mini Review}

Volume 3 Issue 1

Received Date: January 16, 2018

Published Date: February 02, 2018

Rorschach, Department of the Psychiatric Hospital of Havana, Havana Center, Havana city, Cuba, E-mail: cagliostroduenas@gmail.com

\section{Abstract}

In this article, the dynamic and functional relationship between Rorschach, Personality and Culture is established, based on the fact that Rorschach Psycho diagnosis is the ideal psychological instrument to know and unravel the man-culture relationship, and the only one capable of grasping the intra psychic mechanism that interconnects the three great spheres (cognitive, affective and cognitive) that make up the human personality.

Keywords: Rorschach Psycho Diagnosis; Personality; Culture; Humanist Psychology; Cultural Anthropology

\section{Introduction}

True knowledge does not lie in knowing, but in seeking. Leo Buscaglia It is not possible, in any way, to establish Rorschach-Personality-Culture relationship without first making the conceptual characterization of each of these terms. Rorschach Psycho diagnosis [1] is a method of perceptual, empirical and projective personality research, "whose purpose is to obtain information about the intelligence, aptitudes, emotional attitudes and behavioral traits of a person." Designed "by the Swiss psychiatrist Hermann Rorschach (1884-1922), it consists in the interpretation of the content of ten abstract and symmetrical inkblots, obtained by folding, in black and white, white, black and red, and others in color." (www.wikipedia.com).

From another point of view, the Rorschach is the most complete and complex psycho diagnostic instrument known, until today, in the field of neurosciences, because it is the only psychological tool characterized, basically, by its multidimensionality, which offers the researcher (psychologist, psychiatrist or neurologist) a global and integrating vision of the personality (including its ego defenses); it can diagnose any psychic or organic-cerebral condition, as well as establishing the evolutionary prognosis of the mental or neurological disorder, registered by means of that method of investigation of the personality ... unique and unrepeatable. However, it would be worth clarifying the fact that Rorschach Psycho diagnosis is not only used -with satisfactory results- in clinical practice, but also in the field of sociocultural research [2-12], as well as in the area of operation of the different branches of psychological science.

According to the conceptions supported by Psychology with a humanist approach [13-15], man is an unfinished and endless being, imperfect but perfectible, that integrates into a living unit all his dimensions: corporal, psychological, social and spiritual [16], while Elizabeth Kübler-Ross [17], Swiss psychiatrist expert in Thanatology, estimates that the "human being is 


\section{Psychology \& Psychological Research International Journal}

constituted by four quadrants: the physical, the emotional, the intellectual and the spiritual." Quadrants that, from birth to the end of earthly existence, develop gradually and progressively and establish an intimate and close relationship with each other. With support in this line of ethical-humanist thinking, personality is nothing more than the dynamic and functional integration of the biological, psychological, social and spiritual factors on which the essentially human dimension of Homo sapiens is structured [16].

From other theoretical-methodological positions, Allport conceptualizes personality as "the dynamic organization within the individual of the psychophysical systems that determine its characteristic behavior and thought" [18], while Etxeberria and Torrealday conceive it as "the integration of all the traits and characteristics of the individual that determine a proper way of behaving " [19].

Culture is nothing else than "the set of distinctive spiritual and material, intellectual and emotional features that characterize a society or social group. The term culture also includes ways of life, ceremonies, art, inventions, technology, value systems, fundamental human rights, traditions and beliefs. Through culture, man expresses himself, becomes aware of him, questions his achievements, seeks new meanings and creates works that transcend him". (www.wikipedia.com).

From another perspective, culture is the set of material and spiritual goods created by the intelligence and aesthetic sensibility of the sovereign of creation in its constant socio historical evolution, and therefore, the exclusive patrimony of humanity [20], while, for Bustamante and Santa Cruz [21], "culture is a socioeconomic organization, with a group (ethnic or multi-ethnic) ... that inhabits it, that is the result of that culture, and that in turn modify and realize that culture". According to this definition, man and culture integrate a dialectical unity. So much so, that in Sigmund Freud's opinion [22], "the human being falls into neurosis because he cannot bear the degree of frustration imposed on him by society for the sake of his ideals of culture."

Based on these conceptual premises, I will outline the link between Rorschach, Personality and Culture.

From an analytical-humanist perspective [23], I perceive Rorschach Psycho diagnosis not only as a genuine expression of the harmonious relationship between human goodness and beauty, science and art, since all of them occupy a common place in the spiritual component of the Freudian unconscious [22-25], but also as a result of the influence exerted by the historicalcultural environment, where the illustrious Swiss psychiatrist lived and developed the work that immortalizes his name and elevates it -like the eagle- to the summit of contemporary scientific thought [26].

Despite the incontrovertible fact that the Rorschach is a scientific and cultural event [26], "the inkblots, in themselves, are a free stimulus (of the influence) of cultural factors"[11]; stimulus (not implicated from the cultural point of view), which influences the cognitive, affective and cognitive spheres on which the human personality is built [27]. On the other hand, "the protocol (Rorscharchian) is, therefore, (the) personal variant of a cultural pattern, in response to a relatively open situation"[11]. Hence, the environment to which the subject is connected to "perceive, feel, think and act, is always a culturally constituted environment" [11]. In other words, the Rorschach - up to a certain point - can be removed from the determining influence of culture [22], but when the examinee decides to respond coherently to the invitation made by the researcher: "I am going to show you some pictures, and you will tell me what you see in them or what they resemble you", he/she cannot escape such influence. In other words, the subject's response is mediated by socio-cultural programming, which is nothing more than the set of ideas designed by culture, accepted by the society as "absolute truths", and based not on objective realities, but on traditions and interests [28,29]; programming that leaves an indelible mark on the individual's psyche, and he/she stamps it on each and every one of his/her responses to the Rorschach sheets. That is to say, man -seems- cannot underestimate the determining impact of culture [22], and therefore, the responses given by the subject to the Rorscharchian stimulus are modulated by the sociocultural structure [30], which shapes the complex process of formation and consolidation of the personality [27], and therefore, leaves an imprint on the human psyche.

Once reviewed the dialectical relationship between Rorschach, Personality and Culture, I will refer, briefly, to the fundamental indicators approved by the Methodology of Anthropological Research regarding the rational use of psychological instruments, to enter -with success- in a specific field of the cultural life of a nation, people or social group ("civilized" or not, according to cultural norms accepted by western societies belonging to the first world) [11].

These indicators are the following:

They should not be subordinated to cultural factors. 


\section{Psychology \& Psychological Research International Journal}

They should be practically adaptable to the "uneducated" people (those who deviate from the patterns designed by the sacrosanct western culture?).

They should have the possibility to apply to children and adults.

The results should be able to establish group characteristics, as well as offer data on personality variation within the group studied.

With support in our Rorscharchian experience in the field of sociocultural research [2-12], I believe that Rorschach Psycho diagnosis constitutes the psychological ideal instrument to know and unravel the relationship man-culture, since this method of personality research has an eminently perceptual basis and human beings have common modes of perception in the same environment. Methodological indicators that justify the rational use of the Rorschach as a weapon capable of grasping, with exquisite sensitivity, not only the intra psychic mechanism that interconnects the three great spheres that make up the human personality [31], but also "various aspects offered by cultural differences [11]." Therefore, there is no doubt that Rorschach, Personality and Culture are conceptual categories, which interrelate and influence each other.

I would like to end this article with a beautiful quote from Dr. Salvatore Parisi [32], director of the Scuola Romana Rorschach: "the best rorschachists do not live only for the Rorschach, but also for science and art, because only when they deeply love science and art, which is nothing other than loving universal culture, then - and only then - can understand the Rorschach."

\section{References}

1. Rorschach H (1964) Psicodiagnóstico. Buenos Aires: Editorial Paidós.

2. Colli Alonso Mario (2000) Rorschach: su contribución a los estudios sobre personalidad y cultura. La Habana: I Encuentro Cuba-Italia de Psicodiagnóstico de Rorschach.

3. Psiquiatría Folclórica Cubana (2001) oficiantes de los cultos sincréticos como terapeutas folclóricos, también psicoterapeutas? Boletim da Sociedade Rorschach de Sao Paulo 11 (1):17-44.

4. Jesús Dueñas Becerra (1996) Importancia del Psicodiagnóstico de Rorschach para la Antropología Sociocultural. Su actualidad en Cuba. La Habana: ANTROPOLOGÍA-96.
5. E Mantilla (1996) Diagnóstico psicopatológico y terapia folklórica. Estudio de un caso a través del Psicodiagnóstico de Rorschach. La Habana: II Conferencia Internacional de Psicología de la Salud.

6. Jorge Pardillo Palomino (2001) Psicodiagnóstico de Rorschach antes y después de la terapia folclórica. Boletim da Sociedade Rorschach de Sao Paulo 11(1): 45-72.

7. Dueñas Becerra Jesús (2001) Rorschach y Cultura: una reflexión necesaria. Boletim da Sociedade Rorschach de Sao Paulo 11(1): 9-16.

8. Pardillo Palomino, Jorge y Jesús Dueñas Becerra (1998) El bilongo afrocubano: su estudio mediante el Rorschach". Bol Psicol 21 (2): 68-78.

9. Jesús Dueñas Becerra (2001) y Pedro Fernández Olazábal. Psicodiagnóstico de Rorschach. Un manual para la práctica. Camagüey: Editorial Ácana, pp: 123140.

10. Jesús Dueñas Becerra, Mario Colli (2001) Alonso y Gustavo de la Rosa Barbeíto. Psicodiagnóstico de Rorschach y Sincretismo Religioso. Boletim da Sociedade Rorschach de Sao Paulo 11 (1): 73-82.

11. Pradere Campos Elsa (1966) Rorschach y Cultura. Rev Hosp Psiquiatr Hab 7(1): 123-141.

12. Sánchez, Georgina, Jorge Pardillo, M Lima MF (1976) Estudio psiquiátrico y psicológico de un grupo de niños y adolescentes procedentes de un medio con creencias de santería. Rev Hosp Psiquiatr Hab 17 (1): 44-57.

13. García Hernández P Marciano (1995) Para tener vida. Santo Domingo, R.D.: Editorial de Espiritualidad del Caribe.

14. Jesús DB, Noemi PV (1999) Psicología de la experiencia religiosa. Santo Domingo, R.D.: Editorial de Espiritualidad del Caribe.

15. González Rey, Fernando e Hirán Valdés (1994) Psicología Humanista. Actualidad y desarrollo. La Habana: Editorial Ciencias Sociales.

16. Dueñas Becerra, Jesús y Noemí Pérez Valdés (2003) Psicología de la Salud: letra y espíritu. Rev. Cub. Psicol 20(1): 67-70.

17. Kübler-Ross, Elizabeth (1994) Muerte, vida y transición. Ciencias del Espíritu 2(2): 32. 


\section{Psychology \& Psychological Research International Journal}

18. Allport G (1971) La personalidad. Su configuración y desarrollo. La Habana: Editorial Revolucionaria, pp: 47.

19. Etxeberria WA (1994) Torrealday. Teorías de la personalidad. Bilbao: Editorial Berekintza SL, pp: 9.

20. Sorokin PA (1962) Sociedad, Cultura y Personalidad. Madrid: Editorial Aguilar SA.

21. Bustamante José (1975) Ángel y Antonio Santa Cruz. Psiquiatría Transcultural. La Habana: Editorial Científico-Técnica, pp: 63.

22. Freud S (1948) Obras Completas. Madrid: Editorial Biblioteca Nueva 1: 1278.

23. Dueñas Becerra Jesús (2000) Psicoanalista ortodoxo o humanista? Una opinión muy personal. Rev Hosp Psiquiatr Hab 41 (1): 17-22.

24. Jesús DB. Jorge PP, Pedro FO (2002) Rorschach, Personalidad y Espiritualidad. Rev Cub Psicol 19 (3): 209-211.

25. Mannoni O Freud (1984) El descubrimiento del inconsciente. Buenos Aires: Ediciones Nueva Visión.
26. Dueñas Becerra, Jesús (2002) Psicodiagnóstico de Rorschach: antecedentes científicos y artísticos. Rev Cub Psicol 19(3): 205-208.

27. Lersch $\mathrm{Ph}$ (1974) La estructura de la personalidad. Barcelona: Editorial Scientia.

28. Dueñas Becerra, Jesús (2001) Cambio de actitud y estructura sociocultural. Vivarium 18: 45-49.

29. Mello, Anthony de (1994) La iluminación es la espiritualidad. Llama Viva 3: 8-10.

30. Dueñas Becerra (2001) Jesús. Prólogo. En: J. Pardillo y P. Fernández (Eds). Psicodiagnóstico de Rorschach. Un manual para la práctica. Camagüey: Editorial Ácana, pp: 7-8.

31. Pardillo (2001) Palomino Jorge y Jesús Dueñas. Psicodiagnóstico de Rorschach y Epistemología Cualitativa. Rev Cub Psicol 18 (2): 176-179.

32. Parisi S (1998) Las láminas paralelas al Rorschach. La Habana: XX Congreso de la Asociación Latinoamericana de Psiquiatría-II Conferencia Internacional del Hospital Psiquiátrico de La Habana. 